\title{
Determinants of Online Commerce Platform Analyzed with Website Quality Theory
}

\author{
Mahir Pradana \\ Faculty of Communication and Business \\ Telkom University \\ Bandung, Indonesia \\ mahirpradana@telkomuniversity.ac.id
}

\begin{abstract}
In facing the globalization, every business takes advantage in the use of internet to maximize their online platforms. For most online commerce websites in Indonesia, the need to increase their performance comes in form of maximizing online platforms. This study focused on Lazada Indonesia website (www.lazada.co.id) and observed the customers' perception towards its quality. The paper uses Website Quality Theory (WebQual) and the data is descriptive. The research was done by spreading questionnaires to 100 respondents in Bandung to determine what are the factors determining website quality of Lazada Indonesia. The result shows that website's good reputation, detailed information, safe transaction, relevant information, believeable information and information easy to understand are the most determining factors of Lazada website that are perceived by the customers.
\end{abstract}

Keywords- E-Commerce; Website Quality; Information Technology; Online business

\section{INTRODUCTION}

\subsection{OVERALL}

LAZADA INDONESIA is an online shopping center is engaged in IT that offer various types of products such as electronics, books, toys and baby supplies, medical devices and beauty products, household appliances, and fixtures traveling and sports. LAZADA Indonesia was established in 2012 and is one of the branches of the retail network online LAZADA in Southeast Asia. In January 2012, the number of employees LAZADA only 4 people, and in August 2012 the personnel employed rose to 200 employees and continues to grow every month. At the initial launch Lazada has 4000 products sold and divided into 4 categories. Within one week Lazada get his first customer. His first customer was giving testimony regarding satisfaction with the services Lazada.co.id. Good service in terms of its purchase of up to aftersales make Lazada with 1000 subscribers in its first month, a figure which is quite fantastic after one month of the launch of the website. LAZADA have a warehouse or a warehouse of 2,500 square meters and 5,000 square meters in Jakarta, it is an attempt to maintain a growth of $20 \%$ every month. Until December 2012, LAZADA has 13 product categories and more than 3,000 subcategories. In total, the company sold 25,000 kinds of products. In the past year, several times Lazada getting funds from several companies such as JP Morgan and Kinnevik. Besides Indonesia, LAZADA also operates in four Southeast
Asian countries, namely Malaysia, Thailand, Vietnam, and the Philippines. In the past year, LAZADA Indonesia has the largest revenue contribution namely $30 \%$, followed by Thailand (www.lazada.com, accessed June $30^{\text {th }}, 2016$ ).

In addition, most online businesses in developing countries such as in Indonesia have a low penetration to develop their business. Online business arise because of the increasing use of the Internet in the community, thus the existence of the Internet began to shift from conventional to online purchase (Mujiyana \& Elissa, 2013). Online shopping is purchases made via the Internet as a marketing medium with the use of the site (website) as a catalog. One of the advantages of online purchases that shoppers can select products in the catalog, buyers can also request a specific design, to be able to make payments online.

However, they need to increase of the performance and to develop their business Factors such as education, government policy, business competition, and technology are supporting factor that enables businesses to enhance their competitiveness. Various top brands of online shop make the internet users as their target consumers. The leading online store brands in Indonesia are as follows: PT Ecart Service Indonesia (lazada.com), PT OLX Indonesia (olx.com), PT Tokopedia (tokopedia.com), PT Fashion eServices Indonesia (zalora. com), PT Global Digital Commerce (blibli.com), and PT Unity Mentari Dimensions (bhinneka.com). The existence of various online stores are increasing, which becomes an option for internet users to purchase online. Online stores are required to develop various strategies to survive in this industry due to increasing competition. (Wardhana \& Pradana, 2016)

Lazada is the online trading site for products such as:

- Computer and Gadget. Casing and protector, stand and saucers, decorative gadget, cables, speakers, USB flash, etc.

- Furniture. The headboard and bed, chairs, cabinets, desks, tables and park benches, complementary furniture, doors and windows, bookcases and shelves, shoe racks, room divider, sofa.

- Fashion and footwear consists of socks, complementary shoes, sandals, boots, clogs and platform shoes, flats shoes, high heel shoes, moccasin shoes, loafers, sandals, sneakers, shoes wedges. 
- Ornament and Decoration. Decorative pillows, frames, dolls, decorations and ornaments, ornaments parties and celebrations, wall clocks, greeting cards and gifts, paintings and posters, toys and miniatures, wreaths, pins and bookmarks, etc. (Pradana, 2016)

\subsection{Objectives of the Research}

Based on the formulation of the above problems, the objectives to be achieved in this study are: To evaluate the quality of the user's perception Lazada website in the form of usability (usability), quality of information, and the quality of service interaction. Second, to determine the dimensions of the items on which of WebQual contributed the most in the measurement of the quality of the website www.lazada.co.id . Third, to provide advice (recommendations) based on the results of measurements of quality websites about what action should be taken by the management in order to improve the quality of the website. Benefits to be gained from this study are recommendations on how to build a website with good quality governance that is based on the dimensions of Information Quality, Quality of Service Interaction and Usability website.

\section{DISCUSSION}

\subsection{WebQual Theory}

Two most familiar models that are widely used to assess the adoption process in information technology are Technology Acceptance Model (TAM) and Website Quality (WebQual). TAM Provides the basis to Determine the effect of external factors on beliefs, attitudes, and goals of the users.

WebQual instruments on the approach and the importance of user perception. WebQual 1.0 emphasizes the analysis of information quality and has a deficiency in service interaction, WebQual 2.0 put more emphasis on the analysis of the interaction but is sorely lacking on the analysis of the quality of information. Both instruments were to be applied to a study of the quality of online auction sites (Barnes \& Vidgens, 2007). The results showed that Website Quality is categorized into three distinct areas of focus, namely: Quality of the site; The quality of information provided and the quality of interaction offered

The results of this study are known as WebQual 3.0. Further analysis to generate WebQual 3.0 4.0 WebQual model approach which eventually replace the first dimension, namely the quality of the site into a dimension Usability (Usability). The following are tables of dimensions and items that explain WebQual Model 4.0 (Barnes \& Vidgen, 2007).

Barnes dan Vidgen (2007) also describe the theory that: WebQual instrument was developed in the domain of UK business schools. development methodology for the instrument was to use quality function deployment (QFD), which is a structured and disciplined process that provides a means to identify and carry the voice of the customer through each stage of product and or service development and implementation.

Dimensions of WebQual are:

- Usability, which is the quality related to the design of the website
- Information Quality, which is the quality of the content contained on the website, whether or not the information appropriate for the purpose users such as accuracy, format and linkages.

- Interaction Quality, in terms of quality of service interactions experienced by users.

- Overall Impression. The overall look and design of the website was already good.

- $\quad$ (Barnes \& Vidgen, 2007)

Hence, for this research, the questionnaire is structured as follows:

\section{- USABILITY}

1. I find the site easy to learn to operate (01)

2. My interaction with the site is clear and understandable (02)

3. The site has an attractive appearance (03)

4. The design is appropriate to the type of site (04)

5. The site creates a positive experience for me (05)

\section{- INFORMATION QUALITY}

1. Provides accurate information (06)

2. Provides believable information (07)

3. Provides relevant information (08)

4. Provides easy to understand information (09)

5. Provides information at the right level of detail (10)

- SERVICE INTERACTION

1. Has a good reputation (11)

2. It feels safe to complete transactions (12)

3. My personal information feels secure (13)

4. Creates a sense of personalization (14)

\subsection{RESEARCH DESIGN}

a. Type of data comprises qualitative data obtained in the form of resource information on the management of Lazada Website and quantitative data that gathered by calculating the questionnaires given to the respondents to the quality Lazada website.

b. Data source; Primary Data Review includes documentation (reviewing existing documents) and the questionnaire given to the respondent in this case the customers of Lazada.

c. Secondary data consists of data derived from the study of literature in the form of textbooks, journals, internet, results of previous studies.

d. Data Collection Data collection techniques in this study using the technique or instrument: a. Questionnaires are a number of written questions that are used to obtain information from respondents about things that are known or felt. This questionnaire is intended to obtain written 
information from the respondents related to the research objectives.

e. Data analysis use the factor analysis method with the assistance of software SPSS.

\subsection{Population and Sample}

The population sampled in the study are all students of Telkom University in 2014. Because the population is known then the probability sampling technique by using simple random sampling (Simple Random Sampling). Because the population in this study is known, making the number of samples authors use Slovin formula:

$$
\begin{aligned}
& n=\frac{N}{1+N e^{2}} \\
& \text { While : } \\
& \mathrm{n}=\text { sample size } \\
& \mathrm{N}=\text { total population } \\
& \mathrm{e}=\text { degree of tolerance }
\end{aligned}
$$

This research uses a reliability level of $90 \%$ for use of leeway inaccuracy rate of $10 \%$. According to Sugiyono (2013), rounding up because based table sample size and margin of error for the study $10 \%$ level clearances. If the calculation is done using the formula, the minimum amount that was obtained was:

$$
\begin{gathered}
\mathrm{n}=\frac{N}{1+\mathrm{Ne}^{2}}=26.805 / 1+26.805(0.1)(0.1)= \\
=\mathbf{1 0 0} \text { respondents }
\end{gathered}
$$

All respondents are students Telkom University has never used e-commerce website Lazada and all live in Bandung.

\section{RESULTS}

\subsection{Descriptive Analysis of the Data}

Testing Bartlett's test of Sphericity can be used to test the accuracy of the model factors. KMO is useful to measure the feasibility of the sample.

TABLE I. KMO AND BARTLETT'S TEST

\begin{tabular}{|c|r|}
\hline \multicolumn{2}{|c|}{ Kaiser-Meyer-Olkin Measure of Sampling } \\
Adequacy. \\
Bartlett's Test of Sphericity Approx. Chi-Square \\
df & 706.834 \\
Sig. & .000 \\
\hline
\end{tabular}

The table I above showed KMO and Bartlett's test. The output shows the number KMO and Bartlett's test was 0.893 was significantly above 0.5 with 0.000 is below 0.05 then the variables and sample it deserves to be analyzed further.

Anti image correlation. Data on 29 variables derived from the answers of 120 respondents were analyzed in the antiimage correlation, indicating criteria MSA figure above 0.5. which means that the variable can still be predicted to be further analyzed (Santoso, 2002: 101). From the above test results, all variables that have fairly high correlation with other variables, making it feasible to proceed with the analysis include all the variables.

Factoring and Analysis rotation communalities. Communalities is essentially the amount of variance (can be in percentage) of a first variable that can be explained by factors that exist. (Santoso 2002: 117). For example, the variable 01 (website easily understood), the rate of 0.810 means that $81 \%$ variance of variable fineness of the fabric can be explained by factors formed, as with other variables. All variables can be explained by factors formed with the greater communalities provisions of the increasingly close relationship variables concerned with factors formed. It can be seen in table II.

TABLE II.
\begin{tabular}{|c|c|c|}
\hline & COMMUNALITIES \\
\hline & Initial & $\begin{array}{c}\text { Extra } \\
\text { ction }\end{array}$ \\
\hline VAR00001 & 1.000 & .810 \\
VAR00002 & 1.000 & .700 \\
VAR00003 & 1.000 & .422 \\
VAR00004 & 1.000 & .729 \\
VAR00005 & 1.000 & .778 \\
VAR00006 & 1.000 & .746 \\
VAR00007 & 1.000 & .559 \\
VAR00008 & 1.000 & .564 \\
VAR00009 & 1.000 & .378 \\
VAR00010 & 1.000 & .619 \\
VAR00011 & 1.000 & .685 \\
VAR00012 & 1.000 & .613 \\
VAR00013 & 1.000 & .489 \\
VAR00014 & 1.000 & .797 \\
\hline
\end{tabular}

The total variance explained. In Table Total Variance Explained (in Appendix-1), 14 variables that are analyzed can be grouped into three factors, namely the eigenvalues which indicates the number is greater than one. Thus there are three factors formed. Factor loadings are the correlation between the magnitude of each variable determining the variables that enter each factor is done by comparing the magnitude of the correlation on each line. Figures correlations below 0.5 indicate 
a weak correlation indication while above 0.5 indicate a strong correlation. Rotated component matrix is shown in table III.

TABLE III. ROTATED COMPONENT MATRIX $^{\mathrm{A}}$

\begin{tabular}{|c|c|c|c|}
\hline & \multicolumn{3}{|c|}{ Component } \\
\cline { 2 - 4 } & 1 & 2 & 3 \\
\hline VAR00011 & .763 & .258 & .192 \\
\hline VAR00010 & .748 & .145 & .198 \\
\hline VAR00012 & .652 & .420 & .107 \\
\hline VAR00008 & .617 & .204 & .376 \\
\hline VAR00007 & .579 & .095 & .463 \\
\hline VAR00009 & .563 & .220 & .115 \\
\hline VAR00014 & .224 & .850 & .157 \\
\hline VAR00001 & .197 & .836 & .267 \\
\hline VAR00002 & .320 & .737 & .231 \\
\hline VAR00013 & .337 & .548 & .273 \\
\hline VAR00005 & .120 & .318 & .814 \\
\hline VAR00006 & .297 & .140 & .799 \\
\hline VAR00004 & .319 & .167 & .774 \\
\hline VAR00003 & .125 & .369 & .520 \\
\hline
\end{tabular}

Determining which factor entered variables determined by looking at the largest correlation value. In the above table have been sorted from the largest value to the smallest per factors (Hidayat, 2014). From the table above, it appears that Factor 1 contains variable $11,10,12,8,7$ and 9 . The second factor variable load 14, 1, 2 and 13. The three factors make variable $5,6,4$ and 3 .

Once the factors are formed, it turns out the variables that go on each factor is not the same as predicted earlier. Therefore, the need to provide the name of the new label representative for the variables entered in each of the following factors

\subsection{Factor Naming}

- Factor 1 consists of variable 11 (good reputation), 10 (detailed information), 12 (safe transaction), 8 (relevant information), 7 (believeable information) dan 9 (information easy to understand).

- Factor 2 consists of variable 14 (sense of personalization), 1 (website easy to operate), 2 (website interaction is clear and understandable) and 13.

- Last but not least, factor 3 consists of variable 5 (positive experience), 6 (accurate information), 4 (appropriate design) and 3 (attractive appearance).

\section{CONCLUSION}

The factors that the users acknowledge from lazada.co.id website are variable 11 (good reputation), 10 (detailed information), 12 (safe transaction), 8 (relevant information), 7 (believeable information) and 9 (information easy to understand). Afterwards, there are less-determining factors which are variable 14 (sense of personalization), 1 (website easy to operate), 2 (website interaction is clear and understandable). Last but not least, factor 3 consists of variable 5 (positive experience), 6 (accurate information), 4 (appropriate design) and 3 (attractive appearance).

\section{REFERENCES}

[1] Mujiyana, Mujiyana, and Ingge Elissa. "Analisis Faktor-Faktor yang Mempengaruhi Keputusan Pembelian Via Internet pada Toko Online." J@ TI UNDIP: JURNAL TEKNIK INDUSTRI 8.3 (2013): 143152.

[2] Wardhana, Aditya \& Mahir Pradana (2016), Viral Marketing Determinants of Top Online Shop Brands in Indonesia. Mimbar Social and Development Journal. Volume 32 no.1 (June, 2016). 25-30.

[3] Pradana, Mahir (2016), The Usefulness of Online Platform to Increase Small Medium Enterprise (SME)'s Performance (Case Study: Qlapa Indonesia), International Scientific Conference Economic Strategy New Realities: Mechanisms, Tools, Technologies, Rostov-Don, Russia. Unpublished.

[4] Barnes, Stuart J., and Richard Vidgen. "Interactive e-government: Evaluating the web site of the UK Inland Revenue." International Journal of Electronic Government Research 3.1 (2007): 19.

[5] Santoso, Singgih, 2002, SPSS Statistik Multivariat, PT Alex Media Komputerindo, Jakarta. 2001, Statistik Non Parametrik, Buku Latihan SPSS, PT Alex Media Komputerindo, Jakarta

[6] Sugiyono, P. D. "Metode Penelitian Manajemen." Bandung: ALFABETA, CV(2013).

[7] Hidayat, Anwar (2014): Interpretasi Analisis Faktor. www.statistikian.com 